\title{
PEMIKIRAN ETIKA MULLA SHADRA
}

\author{
Andi Safri Bachtiar \\ Pascasarjana UIN Alauddin Makassar
}

\begin{abstract}
Abstrak
Para pemikir muslim berpendapat bahwa etika merupakan ilmu pengobatan rohani yang sangat dibutuhkan manusia, terlebih dalam keadaan yang serba tidak menentu seperti sekarang ini,kondisi psikologis dan mental masyarakat akhir-akhir ini menunjukkan dekadensi moral yang mengkhawatirkan. Oleh karena itu pengkajian di bidang etika semakin dirasakan urgensinya, di samping itu etika filosofis yang dikembangkan para filosof muslim juga perlu mendapatkan perhatian serius.Salah seorang filosof besar yang memiliki peran penting bagi dunia intelektual Islam yakni Mulla Shadra. Pada era Mulla Shadra ini, telah melahirkan sebuah nuansa filsafat baru yang dipelajari secara intensif dengan berbagai analisis serta memberikan sintesis dan integrasi dari filsafat-filsafat sebelumnya. dengan pemikiran-pemikirannya dalam filsafat hikmah yang brilian dan orisinil mampu menjawab semua tantangantantangan moral pada masanya.
\end{abstract}

Kata Kunci: Mulla Shadra, Etika Filosofis, Filsafat Hikmah

\begin{abstract}
The muslim thinkers argue that ethic is the science of spirit therapy that is necessary for human being and even is in a uncertain condition like psychology and mental societies lately who show unstable moral decadence. Hence, the study of ethic aspect is so urgent. Besides, philosophical ethic that is developed by the muslim philosophers need to get the attention seriously. One of them having the essential role for intellectual world of Islam is Mulla Shadra. In his Era, Mulla Shadra built a nuance for new philosophy that is learned intensively with kind of the analysis as well as imparting syntheses and integrations from previous philosophers. By the thought in briliant and original philosophy aspect, he is able to answer all moral challenges in his era.
\end{abstract}

Keywords: Mulla Shadra, philosophical ethic, philosophy 


\section{PENDAHULUAN}

Dalam pemikiran Islam (Islamic thouhgt), muncul studi-studi tentang moral atau etika yang dilakukan oleh para pemikir dan filosof Islam seperti Ibn Bajah, al-Ghazali, Ibn Maskawaih, Mulla Shadra, Murtadha Muthahhari, Muhammad Taqi Mishbah Yazdi dan lain-lain.

Perkembangan pemikiran manusia selalu menarik untuk dikaji. Manusia yang berfikir adalah manusia dinamis, yang akan berevolusi menuju puncak kesempurnaannya sebagai makhluk Tuhan.

Berfikir adalah sebuah aktivitas awal yang menggerakkan seluruh aktivitas kemanusiaan. Para filosof adalah manusia-manusia pilihan yang mengabdikan dirinya pada pergulatan keilmuan dan pemikiran yang tiada henti. Kehadiran para filosof telah memberikan warna tersendiri bagi kehidupan di dunia ini. Setidaknya mereka mampu mengabstraksikan realitas yang dilihat utamanya dalam konsep-konsepnya tentang etika.

Dalam pandangan Mulyadhi Kartanegara bahwa pengkajian di bidang etika dirasakan semakin urgen dikarenakan pelbagai persoalan moral muncul dengan sangat memalukan. Etika menurut para pemikir Muslim, tiada lain adalah ilmu pengobatan rohani yang sangat dibutuhkan manusia, di mana saja dan kapan saja, lebih-lebih dalam keadaan yang serba tidak menentu seperti sekarang ini. Terdapat banyak karya agung perihal etika yang isu-isu moralnya cukup menarik untuk diperbincangkan, misalnya perihal kebahagiaan, pembinaan karakter, pelbagai keutamaan dan penyakit moral, serta pelbagai solusi bagi pelbagai masalah yang timbul. Seperti Tah $d z \hat{\imath} b$ al-Ahklâq karya Ibn Miskawaih, Nashirian Ethics karya Nashîr al-Dîn Thûsî, al-Akhlâq wa al-Siyâr karya Ibn Hazm,Akhlâq-I Jalâlî karya Jalâl al-Dîn al-Dawwânî, serta karyakarya filosof Muslim kontemporer seperti Falsafe Akhlâq karya Murtadla Muthahhari.(Mulyadhi Kartanegara, 2011:4)

Perkembangan filsafat Islam kontemporer dan modern, atau yang lebih dikenal sebagai filsafat pasca Ibn Rusyd. Banyak sekali filosof Muslim yang telah menyumbangkan karya-karya orisinil mereka di bidang filsafat pasca Ibn Rusyd, namun sayang perhatian kita masih sangat minim. Seperti Suhrawardi, Quthb al-Din Syirazi, Nashir al-Din Thusi, Syam al-Din Lahiji, Mulla Shadra, 'Abd al-Razzaq Lahiji, Muhsin Faydl Kasyani, dan lain-lain. Mereka adalah 
para tokoh baru yang namanya terdengar samar-samar. Beberapa tokoh yang hidup pada abad kedua puluh seperti Astiyani, Thabathaba'i, Murtadha Muthahhari, dan Mehdi Ha'iri Yazdi, adalah para tokoh yang mesti dikaji secara intensif dan serius. Karena, dalam karya mereka tercermin bagaimana reaksi para fiolsof Muslim terhadap perkembangan filsafat Barat. (Mulyadhi Kartanegara, 2011)

Salah seorang filosof besar yakni Mulla Shadra sangat memiliki peran penting bagi dunia intelektual Islam setelah Ibnu Sina, Al Ghazali, Ibn Rusyd dan Suhrawardi. Pada era Mulla Shadra ini, telah melahirkan sebuah nuansa filsafat baru yang dipelajari secara intensif dengan berbagai analisis serta memberikan sintesis dan integrasi dari filsafat-filsafat sebelumnya. Pola pemikiran Mulla Shadra, seperti halnya para filosof dan sufi yang mengembangkan pemikiran sebelumnya, baik dari guru maupun tokoh yang berpengaruh pada waktu itu.

\section{PEMBAHASAN}

\section{Biografi Mulla Shadra}

Nama lengkap Mulla Shadra adalah Muhammad bin Ibrahim bin Yahya al-Qawami al-Syirazi, dan diberi gelar "Shadr al-Din, lebih popular dengan sebutan Mulla Shadra atau Shadr al-Muta'allihin.(Syaifan Nur, 2002: 42-43)

Mulla Shadra adalah salah seorang filosof Muslim terbesar. Dia dilahirkan diSyiraz sekitar tahun 979-80 H/ 1571-72 M dalam sebuah keluarga yang cukup berpengaruh danterkenal, yaitu keluarga Qawam. Ayahnya adalah Ibrahim bin Yahya al-Qawami al-Syirazy salahseorang yang berilmu dan saleh, dan dikatakan pernah menjabat sebagai Gubernur Propinsi Fars.Secara sosial-politik, ia memiliki kekuasaan yang istimewa di kota asalnya, Syiraz. (Syaifan Nur, 2002: 42-43)

Mulla Shadra mendapatkan pelajaran pertama di kota Syiraz. Selain dibimbing oleh keluarganya yang juga berasal dari keluarga terpandang dan terpelajar, ia juga mendapatkan pelajaran dari sekolah dasar di kota tersebut. (Syaifan Nur, 2002: 44)

Mulla Shadra adalah murid pertama dari Syaikh Al-Baha'i dan kemudian murid dari Mir Damad, pendiri mazhab filsafat Islam Isfahan. Di bawah 
asuhan keduanya Mulla Shadra memiliki keunggulan ilmu di bidang filsafat, tafsir, hadis, dan irfan.(Murtadha Muthahhari, T.th.: 13)

Mulla Shadra selama empat belas tahun berdiam di Kahak, sebuah desa di Qum untuk melakukan uzlah akibat tuduhan sebagai murtad oleh para seterunya. Pada saat itu, ia mencurahkan seluruh hidupnya untuk membaca dan menulis buku. Pada tahun-tahun terakhir hidupnya, dia diminta untuk mengajar di Madrasah-ye Khan.(Murtadha Muthahhari, T.th.: 13)

Para sejarahwan membagi kehidupan Mulla Shadra ke dalam tiga periode: periode pertama, pendidikan formalnya berlangsung di bawah asuhan guruguru terbaik pada zaman itu, ia menerima pendidikan dalam tradisi Syiah: fiqih Jafari, ilmu hadis, tafsir, dan syarah al-Qur'an di bawah asuhan Baha' al-Din al-Amili, yang meletakkan dasar dari fiqih baru Syiah. Pada tahap berikutnya, dia mempelajari ilmu-ilmu filosofis di bawah asuhan Mir Damad. (Murtadha Muthahhari, T.th.: 13)

Setelah Mulla Shadra merampungkan pendidikan formalnya, ia terpaksa meninggalkan Isfahan, karena kritik sengit terhadap pandanganpandangannya dari kaum Syiah dogmatis. Dan dalam periode kedua, dia menarik diri dari khalayak dan menjalani uzlah di sebuah desa kecil dekat Qum. Selama periode ini pengetahuan yang pernah diperolehnya mengalami kristalisasi yang semakin utuh, dan kreativitasnya menemukan tempat penyalurannya. Dalam periode ketiga, dia kembali sebagai pengajar di Syiraz, dan menolak tawaran untuk mengajar atau menduduki jabatan resmi di Isfahan. Semua karya pentingnya dilahirkan dalam periode ini, dia menghidupkan semangat kontemplatifnya dan melakukan praktek asketis, beberapa argument filosofisnya diperoleh melalui pengalaman-pengalaman mukasyafah.(Murtadha Muthahhari, T.th.: 13)

Karya-karyanya meliputi hampir lima puluh tentang pelbagai persoalan di hampir setiap disiplin ilmu-ilmu tradisional Islam, di antaranya: Al-Hikmah al-Arsyiyyah, Al-Hikmah al-Muta'alliyah fi al-Asfar al-'aqliyyah al-Arba'ah, AlLamaiah al-Masyriqiyyah fi al-Funun al-Mantiqiyyah, Al-Mabda' wa al-Ma'ad, Al-Masya'ir, Al-Mazahir al-Ilahiyyah fi al-Asrar al-'Ulum al-Kamaliyyah, AlSyawahid al-Rububiyyah fi al-Manahij al-Sulukiyyah, Al-Tasawwur wa alTasdiq,dan masih banyak lainnya.(Mustamin Al-Mandary, 2003: 11-12)

Mulla Shadra membangun mazhab baru filsafat dengan semangat untuk

KURIOSITAS | Vol. 11, No. 1, Juni 2017 
mempertemukan berbagai aliran pemikiran yang berkembang di kalangan Muslim seperti Al-Farabi, Ibn Sina, Suhrawardi, Ibn 'Arabi, serta tradisi klasik kalam (teologi dialektis) melalui Nashiruddin al-Thusi. Tidak hanya itu, di samping itu juga mendalami ilmu tentang al-Qur'an dan hadis.(Murtadha Muthahhari, T.th.: 13)

Mulla Shadra telah menghabiskan hidupnya di beberapa tempat, selain di Syiraz, Qaswin, Isfahan, Qum dan desa Kahak, terdapat beberapa catatan yang menunjukkan bahwa Mulla Shadra juga pernah ke beberapa kota suci di Irak, selain ke kota suci Makkah yang dilakukannya dengan jalan kaki, dia juga ke Masyhad, dan akhirnya dalam perjalanan hajinya yang ketujuh dengan jalan kaki, Mulla Shadra jatuh sakit di kota Basrah, Irak. Tidak lama berselang dalam sakit yang dideritanya Mulla Shadra akhirnya kembali kepada Allah pada tahun $1640 \mathrm{M}(1050 \mathrm{H})$, atau dalam sumber lain dikatakan tahun 1636 M (1045 H) atau 1637 M. Mulla Shadra dimakamkan di kota Najaf, tempat Amirul Mukminin Ali bin Abi Thalib dimakamkan. (Mustamin Al-Mandary, 2003: 6)

\section{Pemikiran Etika Mulla Shadra}

Eramodern di satu sisi menawarkan manusia kemudahan hidup dalam segala hal. Namun di sisi lainnya, kenyataan menunjukkan bahwa masyarakat dunia secara umum tengah mengalami krisis multidimensional, termasuk moral dan spiritual. Sehingga pada akhirnya menggiring umat manusia ke arah kehampaan nilai-nilai untuk kemudian terasingkan dari poros eksistensi. Beberapa contoh kasus ekstrem yang mewarnai dunia, orang yang bergelimang harta kekayaan materi namun memilih bunuh diri karena kehampaan dalam hidupnya, juga orang-orang yang demi kepentingan pribadi atau golongannya mengabaikan nilai moral dengan melakukan kezaliman, kekerasan dan peperangan (dalam skala yang lebih besar). Semua ini menunjukkan kurangnya kearifan \& kebijaksanaan dalam memaknai kehidupan.

Salah satu penyebabnya adalah akibat cara pandang dunia (worldview) yang dianggap sudah mapan akan tetapi tanpa disadari telah mengesampingkan aspek penting lainnya, yakni cara pandang filosofis yang mengusung nilainilai spiritualisme. Paradigma modern di satu sisi berhasil mengembangkan sains dan teknologi yang memudahkan kehidupan manusia, namun di sisi 
lainnya telah mereduksi kekayaan kehidupan manusia itu sendiri. Termasuk juga telah mereduksi nilai-nilai filosofis dan spiritual. Untuk itu dibutuhkan suatu paradigm baru yang lebih holistik, yakni sebuah pandangan dunia baru yang menyeluruh dalam mempersepsi realitas. Hal ini dapat ditemukan dalam filsafat hikmah yang dapat dijadikan landasan bagi pengembangan ilmu pengetahuan yang sejalan dengan spiritualisme.

Melalui pandangan yang lebih filosofis dan holistik, diharapkan ada interaksi yang erat antara filsafat (dalam hal ini filsafat hikmah) dengan disiplin-disiplin ilmu lainnya, apalagi ilmu filsafat pernah diterima secara luas sebagai "mother of science". Pandangan ini mengharapkan suatu pencapaian integrasi ilmu, meskipun dengan berbagai sumber fakultas yang berbeda namun terintegrasi dengan harmonis. Karena manusia telah dianugerahi secara komplit, berbagai macam sumber fakultas untuk mencerap nilai dan pengetahuan untuk memaknai kehidupannya. Hal ini diharapkan dapat menghilangkan dikotomi antara ilmu agama yang bersumber dari wahyu ilahi dan yang nonagama, dikotomi antara ilmu sains yang bersumber dari pengamatan empiris (melalui indera) dengan ilmu filsafat yang bersumber dari pemikiran rasional (melalui akal), juga dikotomi antara ilmu filsafat dan ilmu tasawuf/irfan yang bersumber dari pengalaman spiritual (melalui dzauq/ intuisi kalbu).

Dalam hal ini, seorang filosof Muslim bernama Mulla Shadra, dengan pemikiran-pemikirannya dalam filsafat hikmah yang brilian dan orisinil mampu menjawab semua tantangan itu. Filsafat hikmah merupakan evolusi dari filsafat Islam yang bagi sebagian besar orang, dianggap telah berakhir hanya sampai masa Ibn Rusyd, dan diikuti dengan menurunnya Peradaban Islam. Namun di bagian wilayah lain, filsafat Islam tetap bertahan dan berkembang menjadi filsafat hikmah yang diperkenalkan Mulla Shadra. Filsafatnya bukan hanya didasarkan pada pengalaman trans-intelektual dan gnostik, tetapi juga berupa sistem rasional yang solid. Ia berjasa dalam menunjukkan dan menawarkan cara pandang holistik menuju paradigma keilmuan yang islami, karena beliau mampu menjembatani filsafat sebagai "mother of science" dengan ilmu agama/teologi dan tasawuf/irfan secara harmonis.

Pemikiran beliau juga unik, dibingkai dengan nilai spiritualitas sebagai suatu perjalanan yaitu: 1) Dari Mahkluk menuju Tuhannya (min al-khalq ila 
al-Haqq), 2) Dengan Tuhan dalam Tuhan (bi al-Haqqfi al-Haqq), 3) Dari dan dengan Tuhan menuju makhluk (min al-Haqq ila al-khalq), dan 4) Dalam makhluk dengan Tuhan (bi al-Haqq fi al-khalq). (Mustamin Al-Mandary, 2003: 178)

Etika, bersama politik dan ekonomi, dalam khazanah pemikiran Islam biasa dimasukkan dalam apa yang disebut sebagai filsafat praktis (al-hikmah al-amaliyah). Filsafat praktis berbicara tentang segala sesuatu sebagaimana seharusnya. Namun demikian tetap harus didasarkan pada filsafat teoretis (al-hikmah al-nazhariyyah), yakni pembahasa sesuatu sebagaimana adanya, termasuk di dalamnya metafisika.( Haidar Bagir, 2005: 193)

Dalam pandangan berbagai pemikir dan filosof Muslim, ada beberapa prinsip utama etika Islam di antaranya, pertama, etika bersifat universal dan fitri, sebagaimana sabda Nabi Muhammad Saw bahwa perbuatan baik adalah yang membuat hatimu tenteram, sedangkan perbuatan buruk adalah yang membuat hatimu gelisah. Dalam pandangan atau teori etika dari filosof Yunani klasik, Sokrates yang dipromosikan oleh Plato, menyatakan bahwa moralitas itu bersifat fitri, yaitu pengetahuan baik buruk atau dorongan untuk berbuat baik sesungguhnya telah ada pada sifat alami pembawaan manusia (fitrah/innate nature). ( Haidar Bagir, 2005: 195)Kedua, moralitas dalam Islam didasarkan kepada keadilan. Ketiga, tindakan etis pada puncaknya akan menghasilkan kebahagiaan bagi pelakunya_bagi Aristoteles bahwa pada puncaknya tujuan dari tindakan-tindakan etis adalah kebahagiaan yang bersifat intelektual.

Berkaitan dengan kebahagiaan ini, Mulla Shadra menyatakan sangat bergantung kepada kesempurnaan jiwa dalam proses inteleksi (ta'aqqul). Lebih lanjut Shadra mengatakan bahwa pengetahuan dapat mengalih bentuk orang yang tahu dalam proses trans-substansi (harkah jauhariyah-nya) menuju kesempurnaan.

Ada tiga akar (kejahatan) yang dapat merusak jiwa, dari ketiga tersebut muncul akar-akar kejahatan yang lain.Akar yang pertama adalah kebodohan tentang pengetahuan diri yang merupakan realitas manusia. Yang kedua adalah keinginan terhadap kedudukan, uang serta kecenderungan kepada hawa nafsu. Dan yang ketiga adalah godaan jiwa yang memerintah (nafs alammarah) yang menunjukkan keburukan sebagai kebaikan dan kebaikan 
sebagai keburukan. (Mustamin Al-Mandary, 2003: 178)

Menurut Mulla Shadra, bahwa berfilsafat sama maknanya dengan hikmah, ia mendefinisikan filsafat sebagai kesempurnaan jiwa manusia melalui pengetahuan terhadap realitas segala sesuatu yang ada sebagaimana adanya, dan pembenaran terhadap keberadaan mereka yang dibangun berdasarkan bukti-bukti yang jelas, bukan atas dasar persangkaan dan sekedar mengikuti pendapat orang lain, sebatas kemampuan yang ada pada manusia dalam rangka mencapai keserupaan dengan Tuhan. (Syaifan Nur, 2002: 103-104)

Mulla Shadra memandang hikmah ada dua aspek, yaitu teoritis dan praktis atau pengetahuan dan tindakan. Secara teoritis, tujuan hikmah atau pengetahuan adalah mewarnai jiwa dengan gambaran realitas sebagai dunia yang bisa dimengerti, yang menyerupai dunia objektif.

Buah dari pengetahuan (hikmah) menurut Mulla Shadra adalah perbuatan baik, dengan tujuan agar tercapai superioritas jiwa terhadap badan dan badan tunduk kepada jiwa, sebagaimana diisyaratkan Nabi Saw bahwa berakhlaklah kamu dengan akhlak Allah.

Dengan pengetahuan bisa menjadi sarana yang membebaskan manusia dari keterikatan terhadap hal-hal yang bersifat material dan duniawi, dan mengantarkannya kembali kepada asal usul penciptaannya yaitu alam ketuhanan.

Ketika Mulla Shadra menafsirkan firman Allah, "Sesungguhnya Kami telah menciptakan manusia dalam bentukyang sebaik-baiknya. Kemudian Kami kembalikkan dia ke tempat yang serendah-rendahnya. Kecuali orang-orang yang beriman dan mengerjakan amal shaleh." Menurutnya, yang dimaksudkan dengan bentuk yang sebaik-baiknya adalah bagian jiwa manusia yang bersifat spiritual, sedangkan tempat yang serendah-rendahnya menunjukkan bagian manusia yang bersifat material. Adapun orang-orang beriman merupakan isyarat bagi hikmah teoritis, sedangkan amal shaleh mengacu kepada hikmah praktis. (Syaifan Nur, 2002: 105)

Di samping mengusung gagasan-gagasan filsafat dalam school of thoughtfilsafat hikmah, para pemerhati filsafat Shadrian, berpandangan bahwa Mulla Shadra juga mengusung gagasan-gagasan pemerintahan dalam filsafat hikmah. Pendeknya, kata mereka, filsafat hikmah mengajarkan dan mempropagandakan politik hikmah. Menurut Ayatullah Jawadi Amuli bahwa

KURIOSITAS | Vol. 11, No. 1, Juni 2017 
setiap pandangan dunia disertai dengan filsafat praktis dalam kehidupannya.

Hikmah adalah kebijaksanaan (wisdom) yang diperoleh lewat pencerahan ruhaniyah atau intuisi intelektual dan disajikan dalam bentuk yang rasional dengan menggunakan argumen-argumen yang rasional. Hikmah ini bukan hanya memberikan pencerahan kognitif, tetapi juga realisasi, yang mengubah wujud penerima pencerahan itu merealisasikan pengetahuan sehingga terjadinya transformasi wujud hanya dapat dicapai dengan mengikuti syariat. (Jalaluddin Rakhmat,2001: XV)

Filsafat hikmah tidak hanya merupakan sebuah madrasah filsafat dengan teori-teorinya, namun juga merupakan pandangan dunia yang harus dibumikan dalam lakon sehari-hari.Mulla Shadra menuturkan, tujuan eksistensi manusia adalah menjadi penghuni (bumi) dan dalam pergerakan makrifatullah serta menanjak menuju kepada-Nya. Ia memiliki sisi pendaran cahaya dari pancaran-pancaran sinar Ilahi. Manusia lebur dalam cahaya tersebut dan maksud ini tidak akan tercapai kecuali melalui kehidupan di dunia, lantaran nafs (jiwa) pada awal pembentukannya adalah tidak sempurna dan masih berupa potensi. Proses menanjak dari kondisi tidak sempurna kepada kondisi sempurna, tidak akan dapat terlaksana kecuali dengan gerakan (harâkat), zaman dan materi penerima yang merupakan tipologi-tipologi kosmos alam empirik. (Jalaluddin Rakhmat,2001: XV)

Sesuai dengan hukum eksistensial Shadra, gerakan dari kosmos potensial ( quwwah) menuju kosmos aktual ( $\left.f^{\prime} i l\right)$, dari huduts (kebaruan) jasmani kepada baqâ (kekekalan) ruhani, maka mau tidakmau manusia harus berinteraksi dengan majemuk (katsrat/manusia lainnya dan alam semesta) untuk dapat mewujud. Tanpa perhatian terhadap dimensi somatik entitas manusia dan tanpa adanya interaksi sosial maka kesempurnaan hakiki dalam filsafat Shadrian merupakan sesuatu yang mustahil. (Jalaluddin Rakhmat,2001: XV)

Dalam filsafat politik Shadra, manusia dengan ikhtiarnya harus memilih ketika berdiri pada tapal batas material dan spiritual, sisi ruhani dan jasmani. Manusia senantiasa berada di antara majemuk materi (katsrat maddah) dan kesatuan non-materi (wahdat ruhani), sehingga keniscayaan harus bersikap seimbang ( $t a \hat{a} d u l)$ dan berposisi ekuilibrium. Di antara pelbagai kontingenkontingen material, ia harus memilih kontingen-kontingen (imkân) yang tidak menjadi penghalang perhatiannya kepada lokus non-materi dan 
perintang kehadiran (hudhur) pada kesatuan-Nya. Dalam konteks pemilihan sebagaimana kaitan nafs (jiwa) dan fakultas jiwa yang memajemuk, manusia senantiasa berada pada tataran "wahdat dan katsrat" (tunggal dan majemuk) dan "katsrat dan wahdat" (majemuk dan tunggal). Contoh sempurna penggabung ini adalah pribadi unggul Nabi Saw yang ketika pandangannya tertuju pada katsrat (urusan kebendaan dan sosial politik) maka pada saat yang sama perhatiannya tetap tertuju pada maqam wahdat (tunggal). Manusia sebagai salik (pejalan) perjalanan spiritual sepanjang hidupnya dengan memilih antara tarik ulur jasmani dan pelbagai konflik politik sosial maka ia senantiasa berada pada kondisi memilih di antara jamak dan tunggal. (Jalaluddin Rakhmat,2001: XV)

Pemerintahan ideal Sadrian merupakan media untuk moral transendental dan moral transendental Sadrian adalah media untuk terealisirnya politik transendental. Politik transendental merupakan jenis pemerintahan dan aturan-aturan politik sosial dalam Madinah Fâdhilah. Politik transendental ini berada pada poros aturan-aturan yang berlaku bagi kematangan dan kemenjulangan manusia serta moral fadhilah. Persoalan politik adalah politik legal yang memiliki kelayakan segala pra syarat untuk mengaktualisasikan pelbagai kesempurnaan potensial setiap orang. Penyediaan syarat-syarat seperti ini termasuk di dalamnya adalah urusan eskatologi dan keseharian manusia. Pemisahan kebahagiaan jasmani dan kebahagiaan ruhani merupakan suatu hal yang mustahil; sebagaimana dalam definisi esensi manusia dalam filsafat Sadrian, pemisahan dua dimensi jasmani dan ruhani merupakan hal yang mustahil. (Jalaluddin Rakhmat,2001: XV)

Sistem politik ideal dalam Madinah Fâdhilah ala Mulla Shadra adalah sebuah sistem dimana pada saat yang sama menyediakan pelbagai kebutuhan manusia pada dua sisi, jasmani dan ruhani, material dan spiritual. Konsep kebahagiaan, keadilan, kebebasan, dan legalitas politik Sadrian ditentukan dan didefinisikan dengan konsep-konsep ini. Dalam Madinah Fâdhilah Sadrian, umat memiliki dua tipologi khas. Pertama, memiliki cita rasa esensial dan murni kepada kesempurnaan eksistensial, termasuk pelbagai kesempurnaan praktis dan teoritis. Setinggi-tingginya keutamaan dalam masyarakat seperti ini adalah mereka yang mampu menggondol derajat tertinggi keilmuan dan berbusana dengan pakaian-pakaian moral serta bentuk-bentuk pelbagai 
perbuatan baik, menghindar dari perbuatan sia-sia, batil dan sifat-sifat tercela. Kedua, gerakan dan perhatian totalitas kepada tujuan tertinggi yaitu sampai dan perjumpaan dengan Allah Swt. Dalam masyarakat yang menjadikan Tuhan sebagai sentral seperti ini, tentu saja secara natural aturan-aturan Ilahi juga yang berkuasa dan syariat berfungsi sebagaimana ruh bagi seluruh aturan-aturan manusia dan politik yang bermakna modern. (Jalaluddin Rakhmat,2001: XV)

Mulla Shadra juga dalam beberapa disposisi, mengingatkan akan kemestian adanya syariat, wahyu dan intervensi insan kamil sebagai "wali" dalam urusan politik dan sosial sembari menetapkan bagaimana kondisi politik dan kehendak urusan keseharian masyarakat apabila diatur oleh orang-orang yang tidak mengenal hakikat-hakikat spiritual maka umat akan digiring kepada sebuah masyarakat mati dan tanpa ruh serta penuh dengan kerusakan dan destruksi. (Jalaluddin Rakhmat,2001: XV)

Di setiap ruang dan waktu, di setiap tempat dan masa, di setiap masyarakat yang bercita-cita adilhung mencapai kebahagiaan dan kesempurnaan diperlukan seorang yang menjadi insan paripurna yang membimbing dan mengejawantahkan nilai-nilai kesempurnaan dalam kehidupan masyarakat.

Kajian filsafat politik_sebagaimana juga etika_merupakan wilayah/ domain filsafat praktis (al-Hikmah al-Amali). Ini sesuai dengan karateristif filsafat Islam, yang tidak dapat terlepas dari kajian ontologis maupun epistemologis (al-Hikmah al-Nazari/filsafat teoritik) sebagai satu kesatuan sistemik-integratif dari filsafat Islam.

\section{PENUTUP}

Buah dari pengetahuan (hikmah) menurut Mulla Shadra adalah perbuatan baik, dengan tujuan agar tercapai superioritas jiwa terhadap badan dan badan tunduk kepada jiwa, sebagaimana diisyaratkan Nabi Saw bahwa berakhlaklah kamu dengan akhlak Allah.Dengan pengetahuan bisa menjadi sarana yang membebaskan manusia dari keterikatan terhadap hal-hal yang bersifat material dan duniawi, dan mengantarkannya kembali kepada asal usul penciptaannya yaitu alam ketuhanan. 


\section{DAFTAR PUSTAKA}

Bagir, Haidar. Buku Saku Filsafat Islam. Cet. I; Bandung: Arasy Mizan Pustaka, 2005. Efendi, Agus.2000. "Mengenal Mullā Sadrā” dalam Sukardi (ed.), Kuliah-Kuliah Tasawwuf, Cet. I; Bandung, Pustaka Hidayah.

http://www.alhassanain.com. "Filsafat Hikmah dan Politik Hikmah." Diaskes pada tanggal 18 Nopember 2011.

Kartanegara, Mulyadhi. Membangun Kerangka Keilmuan IAIN Perspektif Filosofis, di http://www.ditpertais.net, pada tanggal 18 Nopember 2011.

Al-Mandary, Mustamin (ed).Menuju Kesempurnaan; Persepsi dalam Pemikiran Mulla Shadra. Cet. I; Makassar: Safinah, 2003.

Márifat, Muhammad Hadi.2007.Tarikh al-Quran, diterjemahkan oleh Thoha Musawa dengan judul, Sejarah Alquran, Cet. II, Jakarta: Al-Huda,

Muhsin, Labib.2005Para Filosof Sebelum dan Sesudah Shadra, Cet. I; Jakarta: AlHuda Islamic Center.

Muthahhari, Murtadha. Filsafat Hikmah; Pengantar Pemikiran Shadra. Mizan: Bandung.

Nur, Syaifan. Filsafat Wujud Mulla Sadra. Cet. I; Yogyakarta: Pustaka Pelajar, 2002.

Rakhmat, Jalaluddin. "Pengantar” dalam Mulla Shadra, Kearifan Puncak. Jogyakarta: Pustaka Pelajar, 2001. 